\title{
Crónica
}

\section{Resultados encuesta SOCHOG Proyecto Ley Aborto en 3 causales}

\author{
Disponible en: http://www.sochog.cl/noticias-sochog/resultados-encuesta-sochog- \\ proyecto-ley-despenalizacion-del-abortol
}

Conscientes del activo debate que vive nuestro país con motivo del Proyecto de Ley que propone despenalizar el aborto en 3 causales, así como también de la diversidad de posturas y creencias frente a cada una de estas causales que posee cada uno de nuestros especialistas gineco-obstetras a lo largo del país, la Sociedad Chilena de Obstetricia y Ginecología (SOCHOG) decidió realizar una encuesta de opinión entre sus 689 asociados. Damos a conocer a la opinión pública dichos resultados, con la esperanza de que sean una herramienta que contribuya al debate.

Causal 1: El proyecto de ley considera que, si una mujer expresa su voluntad, un médico cirujano se encuentra autorizado para interrumpir un embarazo cuando: La mujer se encuentre en riesgo vital presente o futuro, de modo que la interrupción del embarazo evite un peligro para su vida.
Causal 2: El proyecto de ley considera que, si una mujer expresa su voluntad, un médico cirujano se encuentra autorizado para interrumpir un embarazo cuando: El embrión o feto padezca una alteración estructural congénita o genética incompatible con la vida extra-uterina.

Causal 3: El proyecto de ley considera que, si una mujer expresa su voluntad, un médico cirujano se encuentra autorizado para interrumpir un embarazo cuando: Es resultado de una violación, siempre que no hayan transcurrido más de 12 semanas de gestación. Tratándose de una menor de 14 años, la interrupción del embarazo podrá realizarse siempre que no hayan transcurrido más de 18 semanas de gestación.

Directorio de la Sociedad Chilena de Obstetricia y Ginecología.

Santiago, 12 de agosto de 2015. 